\title{
Evaluating the effect of writing instructions on students' writing skills
}

\author{
Mehmet Fidan ${ }^{\mathrm{a}}$ * \\ APA Citation: \\ ${ }^{a}$ Aksaray University, Aksaray, Turkey \\ Fidan, M. (2019). Evaluating the effect of writing instructions on students' writing skills. Journal of Language and Linguistic Studies, 15(3), \\ 1069-1082. \\ Submission Date: 04/07/2019 \\ Acceptance Date: 26/07/2019
}

\begin{abstract}
The development of language skills is important at both the individual and social levels. Writing, which is one of these skills, enables individuals to express themselves both aesthetically and permanently. This importance of writing requires special attention to the training for its development. In this research, screening model which is one of the quantitative research methods was used. How the texts written by university students were influenced by the instructions used in written forms was the subject of this research. The students of Aksaray University, Faculty of Education Department of Turkish Education participated in the study. These students were divided into two groups as experimental and control groups. As a result of the research, it was seen that the instructions were effective in terms of number of words and connection expressions. In terms of compliance with spelling and punctuation rules, it was determined that the instructions had no effect on these groups.
\end{abstract}

(C) 2019 JLLS and Mehmet Fidan - Published by JLLS.

Keywords: Writing skills; writing activities; writing instruction.

\section{Introduction}

Writing education has an important position in language education due to the cognitive and sensory processes involved. Speaking skill as well as writing skill is among the means of self-expression. However, compared to the speech acquired in the natural process, writing skills require various educational stages. One of the reasons why writing is important is this feature. In addition to ability of expression, writing is also a means of understanding and therefore learning. Günel, Kabataş Memiş and Büyükkasap (2009: 413) state that writing activities in this direction improve students' learning. Regarding this issue, Günel, Kabataş Memiş and Büyükkasap (2010:61) have also concluded that the Science Writing Heuristic activities positively affect the academic development of students.

Writing education is one of the primary objectives of the mother tongue curriculum. When the specific objectives of Turkish Language Teaching Program are examined, it is seen that special attention is given to the development of written communication skills of the students (MEB, 2018:8). Because of the effect of writing education on cognitive, sensory and communication skills, it is seen that researchers are interested in this field.

\footnotetext{
* Corresponding author Tel.: +90-0352-341-2617

E-mail address: fidanm3838@gmail.com
} 
According to Güneş (2013:1), the role of language has changed with the effect of constructivist approach and the social communication aspect of language has started to be given importance. Güneş (2013:1) states that this situation leads to changes in the structure of the texts used in language teaching. For this reason, this situation should be taken into consideration in the texts written by the students. The development of language skills on the basis of each other requires that these skills interact with each other in the learning processes. Karakoç Öztürk (2012:70) states that the development of students' reading skills affects writing skills in the same direction. As a matter of fact, the strategies used by individuals in this process affect the development of their language skills. In Belet and Yaşar's (2007: 69) research concluded that using learning strategies positively affected the development of reading and writing skills. Similarly, İnal's (2008:62) research states that clustering strategy will improve students' writing skills positively. This situation is important in terms of showing that cognitive processes affect the development of language skills such as reading and writing. According to the researchers, in addition to individual competencies, elements such as teacher and family are also effective in the development of students' writing skills. In Erdoğan's (2017:672) research examined the use of writing strategies by classroom teachers and concluded that teachers did not use these strategies enough. According to Erdoğan (2017:672), this situation may affect students' writing skills negatively. Ungan (2007:469) states that teachers should be taken in-service trainings in this direction in order to take advantage of lessons of writing in this research. Doğan (2003:198) also states that teachers have a direct effect on the development of students' writing skills and therefore, it should be taken into consideration that this situation should be taken into consideration in the training given to teacher candidates. Grossman, Valencia, Evans, Thompson, Martin \& Place (2000:658) state that teacher education can help teacher candidates in their writing education. This situation reveals the teacher-student interaction in the teaching of writing skills as in other language skills. Öztürk (2007: 272) states that in addition to teachers, there are behaviors that families should do in the development of students' creative writing skills. Englert, Raphael, Anderson, Anthony \& Stevens (1991:337) stated that teaching based on students' interaction with teachers and another students positively affected students' writing skills.

There is a holistic structure of writing skills. This holistic structure stems from the fact that writing involves cognitive and sensory skills. This situation requires careful approach to writing education. In this direction, it is seen that the researchers are working on how to improve students' writing skills. Kellogg (2008:22) draws attention to systematic training in the development of writing skills. Kellogg (2008:22) states that "the principles of deliberate practice and cognitive apprenticeship" will be effective in this direction. Kepner (1991:305) examines writing skills in second language teaching. Kepner (1991:311) states that cognitive interest is effective in improving the writing competence of L2 students. Rao (2007:105) States in his research that "the brainstorming strategy instruction" is instrumental in improving students' writing skills. Mak and Coniam (2008:453) point out that the "wiki" project developed intended for secondary school students in Hong Kong in their work, towards improving writing skills is effective in learning English. In addition, Mak and Coniam (2008:453) stated that peer assessment had a positive effect on students' writing skills. In his research, Breland and Jones (1984:118) said that paying attention to the connections between sentences rather than analyzing sentences individually could have a greater impact on the arrival of language skills.

The writing activities in the textbooks play an important role in the development of students' writing skills. Ar1 (2011: 508) in his research on this subject states that there should be a harmony of type between writing tasks and reading texts. Writing skills can be effective not only in language courses but also in other disciplines. Demirbaş (2005: 73) concluded that creative writing studies used in biology course had a positive effect on students' attitudes towards the course. 


\section{Method}

\subsection{Model of research and Instrument}

In this research, screening model which is one of the quantitative research methods was used. According to Karasar (2009: 77), the researcher focuses only on the current situation in the screening model. In this respect, Karasar (2009: 77) states that the researcher does not "attempt to change or influence" the current situation in the screening model. In this study, the effect of the instructions that time, minimum number of words, spelling and punctuation rules used in writing activities, on the texts of the students were investigated. It has been examined whether the existence of these instructions makes a difference in the level of texts in terms of student groups. The research was conducted in the form of writing forms which were applied to the students at regular intervals (3 days). The research process lasted 10 days.

The aim of this study is to determine the effect of the instructions used in writing activities on students' texts in terms of number of words, number of sentences, number of connection expressions, number of proverbs and idioms, spelling and punctuation rules. The research questions of this study are given below:

1. When the time instructions are used in writing activities, which variables affect the texts of the students?

2. When the minimum numbers of word instructions are used in writing activities, which variables affect the texts of the students?

3. When the conform to spelling and punctuation rules instructions are used in writing activities, which variables affect the texts of the students?

\subsection{Participants}

The study group of this research consisted of students of Aksaray University, Faculty of Education Department of Turkish Education. The principle of volunteering was sought in the participation of the students in this research. These were classified as experimental and control groups. In the analysis process of the data in the research process are experiment group: group 1, control group: group 2 was named. The data of the students in the study group are as follows:

Table 1. Working group

\begin{tabular}{llccc}
\hline Groups & $\mathrm{N}$ & Female & Male & Grade 4 \\
\hline Group 1 (experiment) & 10 & 5 & 5 & 10 \\
\hline Group 2 (control) & 10 & 5 & 5 & 10 \\
\hline Total & 20 & 10 & 10 & 20 \\
\hline
\end{tabular}

As shown in Table 1, a total of 20 students participated in the study. All of these students are studying in the 4th year of the undergraduate program. The groups consisted of 10 students. At the group level and in general the number of female and male participants is equal. 


\subsection{Data collection procedures}

In this research, the texts written by the students during the research process were used as a data collection tool. Firstly, the same forms were given to the students in both groups and the students were asked to write essays on the subject in this form. These forms applied to the students were named as pre-tests. Then, in order to determine the differences between the groups, three more forms were applied to the students at certain time intervals. The questions and expressions in the forms applied to both groups were the same. The difference in forms is in the direction of instructions. Forms containing instructions for compliance with time, minimum number of words, spelling and punctuation rules were applied to the experimental group. These instructions were not included in the forms applied to the control group.

Various factors were taken into consideration in determining the instructions in the forms applied to the students participating in the research. The opinions of Turkish teachers were used to determine these instructions. 5 the Turkish teacher was asked which guidelines they used in writing activities. According to their answers, time, minimum number of words, compliance with spelling and punctuation rules was found to be the most commonly used instructions. Therefore, these instructions were used in the forms used in the research process.

The instructions used in writing forms during the research process can be listed as:

Pre-test

Experimental group: Write an essay on the place of technology in your life.

Control group: Write an essay on the place of technology in your life.

Minimum word instruction

Experimental group: "The value of youth is understood in old age, the value of health is understood in disease. In other words, the value of an asset is revealed when it is lost." write a text in line with the main idea. (Use at least 100 words)

Control group: "The value of youth is understood in old age, the value of health is understood in disease. In other words, the value of an asset is revealed when it is lost." write a text in line with the main idea. Instruction to conform to spelling and punctuation rules

Experimental group: Write an essay on "to love without waiting for benefit". (Note the spelling and punctuation rules)

Control group: Write an essay on "to love without waiting for benefit".

Time instructions

Experimental group: Describe a day of the teacher in your ideal. (Your writing time is 20 minutes)

Control group: Describe a day of the teacher in your ideal.

\subsection{Data analysis}

In the research, it was planned to determine quantitative data in order to reach objective data. Because, in determining the quality of a manuscript, besides the qualitative features such as style, subject, logical bond, it is also important to comply with the words, sentences, connection expressions, proverbs, idioms and spelling and punctuation rules used in this manuscript. Various sources have been examined relating this subject. The gains about writing skills in the Turkish Lessons Teaching Program (MEB:2018) and the writing teaching methods section of in the Aktaş and Gündüz (2017) were used in determining these quantitative guidelines. In this study, when specifying connection expressions as variables: "Uses appropriate transition and link expressions in his writings." (MEB, 2018:39), when specifying proverbs and idioms as variables: "He uses proverbs, idioms and maxims to enrich his writings." (MEB, 2018:47), when specifying complying with spelling and punctuation rules as variables: "He/she edits what own writes." (MEB, 2018: 51) acquisitions were source received. In addition, Aktaş 
and Gündüz (2017: 226) also stated that elements such as form, spelling, punctuation, and expression characteristics can be considered in the evaluation of students' texts. In the benefit of these data, these variables in the research forms were analyzed. The data obtained were analyzed using Spss 18 program. Independent samples $t$ test was used to determine the difference between the groups. The sig $(2-$ tailed $)$ values obtained from the independent samples $t$ test were examined. In the analysis stage, values $p<0$, 05 were accepted as significant and it was concluded that this indicates a difference between the groups.

\section{Results}

\subsection{Pre-test findings}

Pre-test results were evaluated first in the study. Pre-test data evaluated under headings. This headings are word, sentence, connection expressions, proverbs, idioms and the minimum number of text and punctuation errors. Table 2, which contains data for independent samples $t$ test results, is given below.

Table 2. Pre-test

\begin{tabular}{|c|c|c|c|c|c|c|}
\hline & $\begin{array}{c}\text { Groups of } \\
\text { Participating } \\
\text { Students }\end{array}$ & $\mathrm{N}$ & $\bar{X}$ & $\mathrm{Sd}$ & $\mathrm{T}$ & $\mathrm{P}$ \\
\hline \multirow{2}{*}{$\begin{array}{l}\text { Number } \\
\text { words }\end{array}$} & \multirow{2}{*}{$\begin{array}{l}\text { Group } 1 \\
\text { Group } 2\end{array}$} & 10 & 128,600 & 19,7495 &,- 124 & \multirow[t]{2}{*}{,903 } \\
\hline & & 10 & 129,900 & 26,7932 &,- 124 & \\
\hline \multirow{2}{*}{$\begin{array}{l}\text { Number } \\
\text { sentences }\end{array}$} & \multirow{2}{*}{$\begin{array}{l}\text { Group } 1 \\
\text { Group } 2\end{array}$} & 10 & 11,6 & 2,91 &,- 132 & \multirow[t]{2}{*}{,896 } \\
\hline & & 10 & 11,8 & 3,79 &,- 132 & \\
\hline \multirow{2}{*}{$\begin{array}{l}\text { Number of } \\
\text { link } \\
\text { expressions }\end{array}$} & \multirow{2}{*}{$\begin{array}{l}\text { Group } 1 \\
\text { Group } 2\end{array}$} & 10 & 11 & 3,19 &,- 983 & \multirow[t]{2}{*}{,339 } \\
\hline & & 10 & 12,6 & 4,03 &,- 983 & \\
\hline \multirow{2}{*}{$\begin{array}{l}\text { Number of } \\
\text { proverb and } \\
\text { idioms }\end{array}$} & \multirow{2}{*}{$\begin{array}{l}\text { Group } 1 \\
\text { Group } 2\end{array}$} & 10 & 1,6 & ,54772 &,- 155 & \multirow[t]{2}{*}{,880 } \\
\hline & & 10 & 1,6 &, 81650 &,- 161 & \\
\hline \multirow{2}{*}{$\begin{array}{l}\text { Number of } \\
\text { spelling and } \\
\text { punctuation } \\
\text { errors }\end{array}$} & \multirow{2}{*}{$\begin{array}{l}\text { Group } 1 \\
\text { Group } 2\end{array}$} & 10 & 3,33 & 1,32288 & ,131 & \multirow[t]{2}{*}{,897 } \\
\hline & & 10 & 3,20 & 2,78089 &, 136 & \\
\hline
\end{tabular}

The researcher were examined the texts written by the participants as a result of the preliminary test in terms of various qualities. Where group 1 represented the experimental group and group 2 represented the control group. The firstly, it is seen that groups are equal in participation to this test. Both groups participated in the test with a total of 10 students. When the texts written by the students participating in the study were analyzed in terms of the number of words, the average number of words in group 1 was 128,6 and the average number of words in group 2 was 129,9 . When this data were analyzed according to independent samples t test, $p>0,05$ results was obtained. This shows that there is no significant difference between the groups in terms of the number of words according to the pre-test results. $(t=-, 124-, 124, p>0,05)$. The similarity of the number of words in the texts written by the students during the pre-test phase provide a suitable data for the other stages of the research.

When the texts written during pre-test phase by the students participating in the research were analyzed in terms of the number of sentences, the average number of sentences of group 1 was found to be 11,6 and the average number of sentences of group 2 was found to be 11,8 . When this data were analyzed according to independent samples $t$ test, $p>0,05$ results was obtained. According to the results of the analysis, it is seen pre-test stage that there is no significant difference between the groups in terms of the number of sentences. $(t=-, 132-, 132, p>0,05)$. The similarity of the number of sentences in the 
texts written by the students in the pre-test stage provide a suitable data for the other stages of the research.

When the texts written during pre-test phase by the students participating in the research were analyzed in terms of the number of connection expressions, the average number of connection expressions of group 1 was found to be 11 and the average number of connection expressions of group 2 was found to be 12,6 . When this data were analyzed according to independent samples $t$ test, $p>0$, 05 results was obtained. According to the results of the analysis, it is seen that there is no significant difference in the number of connection expressions between the groups in the pre-test stage. $(\mathrm{t}=-, 983$ , 983, $\mathrm{p}>0,05)$. The similarity of the number of connection expressions in the texts written by the students during the pre-test phase provide a suitable data for the other stages of the research.

When the texts written during pre-test phase by the students participating in the research were analyzed in terms of number of proverb and idioms, group 1's average was found to be 1,6, group 2's average was found to be 1,6 . When this data were analyzed according to independent samples t test, $\mathrm{p}$ $>0,05$ results was obtained. These results show that the groups in the pre-test stage are equal in terms of the number of proverbs and idioms. ( $\mathrm{t}=-, 155-, 161, \mathrm{p}>0,05)$. The similarity of proverbs and idiom numbers in the texts written by the students in the pre-test stage provide a suitable data for the other stages of the research.

When the texts written during pre-test phase by the students participating in the research were analyzed in terms of the number of spelling and punctuation errors, group 1's average was found to be 3,33 and group 2's average was found to be 3,20. When this data were analyzed according to independent samples $t$ test, $p>0,05$ result was obtained. These results show that there is no significant difference between the groups in terms of the number of spelling and punctuation errors. $(t=, 131,136, p>0,05)$. The similarity of spelling and punctuation errors in the texts written by the students in the pre-test phase provided a suitable data for the other stages of the research.

According to these pre-test findings, it can be said that the groups were similar in terms of the characteristics examined. This situation will help to reach reliable data in order to investigate the effect of - time, number of minimum word, spelling and punctuation rules- on the texts written by students. Research findings of the instructions are given below:

\subsection{Findings of the time instructions}

In the research process, the effect of the time instructions on the texts written by the students after the pre-test phase was examined. At this stage, there was a time instructions in the forms given to group 1 , while the time instructions was not included in the forms given to group 2 . Thus, it is aimed to determine whether the time instructions cause a difference between the groups. Related to this field, data regarding the effect of word, sentence, link expressions, proverb, phrase, and the number of spelling and punctuation errors are located in Table 3.

Table 3. Time instructions

\begin{tabular}{|c|c|c|c|c|c|c|}
\hline & $\begin{array}{l}\text { Groups of } \\
\text { Participating } \\
\text { Students }\end{array}$ & $\mathrm{N}$ & $\overline{\mathrm{X}}$ & $\mathrm{Sd}$ & $\mathrm{T}$ & $\mathrm{P}$ \\
\hline \multirow{2}{*}{$\begin{array}{l}\text { Number } \\
\text { words }\end{array}$} & \multirow{2}{*}{$\begin{array}{l}\text { Group } 1 \\
\text { Group } 2\end{array}$} & 10 & 106 & 34,2766 & 2,500 & \multirow[t]{2}{*}{, $022^{*}$} \\
\hline & & 10 & 72,7 & 24,4769 & 2,500 & \\
\hline \multirow{2}{*}{$\begin{array}{l}\text { Number of } \\
\text { sentences }\end{array}$} & \multirow{2}{*}{$\begin{array}{l}\text { Group } 1 \\
\text { Group } 2\end{array}$} & 10 & 10,8 & 4,41714 & 1,162 & \multirow[t]{2}{*}{,260 } \\
\hline & & 10 & 8,9 & 2,68535 & 1,162 & \\
\hline
\end{tabular}




\begin{tabular}{|c|c|c|c|c|c|c|}
\hline \multirow{2}{*}{$\begin{array}{l}\text { Number of } \\
\text { link } \\
\text { expressions }\end{array}$} & \multirow{2}{*}{$\begin{array}{l}\text { Group } 1 \\
\text { Group } 2\end{array}$} & 10 & 10,7 & 1,32539 & 3,061 & \multirow[t]{2}{*}{,007* } \\
\hline & & 10 & 5,7 & ,95510 & 3,061 & \\
\hline \multirow{2}{*}{$\begin{array}{l}\text { Number of } \\
\text { proverb and } \\
\text { idioms }\end{array}$} & \multirow{2}{*}{$\begin{array}{l}\text { Group } 1 \\
\text { Group } 2\end{array}$} & 10 & 1,5 & ,70711 & $-1,000$ & \multirow[t]{2}{*}{, 423} \\
\hline & & 10 & 2 & ,00000 & $-1,000$ & \\
\hline \multirow{2}{*}{$\begin{array}{l}\text { Number of } \\
\text { spelling and } \\
\text { punctuation } \\
\text { errors }\end{array}$} & \multirow{2}{*}{$\begin{array}{l}\text { Group } 1 \\
\text { Group } 2\end{array}$} & 10 & 2,14 & 1,34519 &,- 140 & \multirow[t]{2}{*}{,891 } \\
\hline & & 10 & 2,25 & 1,58114 &,- 142 & \\
\hline
\end{tabular}

Note: Items marked (*) are items that are significant at $P<0,05$.

When the number of words in the texts written by the students participating in the study was examined in terms of the effect of time instructions, the average number of words of group 1 was found to be 106 and the mean number of words of group 2 was 72,7. When this data were analyzed according to independent samples $\mathrm{t}$ test, $\mathrm{p}<0,05$ results was obtained. This result shows that there is a significant difference between the groups in terms of the number of words. $(t=2,500,2,500, p<0,05)$. According to these data, it can be said that the time instructions affects the number of words in the students' texts. As a matter of fact, it was found that the number of words of group 1 was higher than the other group.

When the number of sentences in the texts written by the students participating in the study was examined in terms of the effect of time instructions, the average number of sentences of group 1 was found to be 10,8 and the mean number of sentences of group 2 was 8,9 . When this data were analyzed according to independent samples t test, $p>0,05$ results was obtained. This result shows that there is no significant difference between the groups in terms of number of sentences. $(t=1,1621,162, p>0,05)$. According to these data, it can be said that the time instructions does not affect the number of sentences in the students' texts.

When the number of link expressions in the texts written by the students participating in the study was examined in terms of the effect of time instructions, the average number of link expressions of group 1 was found to be 10,7 and the mean number of link expressions of group 2 was 5,7. When this data were analyzed according to independent samples t test, $p<0,05$ results was obtained. This result shows that there is a significant difference between the groups in terms of the number of link expressions. ( $t=3,061,3,061, \mathrm{p}<0,05)$. According to these data, it can be said that the time instructions affects the number of link expressions in the students' texts. As a matter of fact, the number of connection expressions of group 1 was found to be higher than the other group.

When the number of proverb and idioms in the texts written by the students participating in the study was examined in terms of the effect of time instructions, the average number proverb and idioms of group 1 was found to be 1,5 and the mean number of proverb and idioms of group 2 was 2 . When this data were analyzed according to independent samples $t$ test, $p>0,05$ results was obtained. This result shows that there is no significant difference between the groups in terms of number of proverb and idioms. ( $t=-1,000-1,000, p>0,05)$. According to these data, it can be said that the time instructions does not affect the number of proverbs and idioms in the students' texts.

When the number of spelling and punctuation errors in the texts written by the students participating in the study was examined in terms of the effect of time instructions, the average number of spelling and punctuation errors of group 1 was found to be 2,14 and the mean number of spelling and punctuation errors of group 2 was 2,25 . When this data were analyzed according to independent samples t test, $p>$ 0,05 result was obtained. This result shows that there is no significant difference between the groups in terms of number of spelling and punctuation errors. $(\mathrm{t}=-, 140-, 142, \mathrm{p}>0,05)$. According to these data, 
it can be said that the time instructions does not affect the number of spelling and punctuation errors in the students' texts.

\subsection{Findings of minimum number of words instructions}

In the research process, after the pre-test phase, the effect of the minimum number of words instructions on the texts written by the students was examined. At this stage, the minimum number of words instructions was found in the forms given to group 1 whereas the minimum number of words instructions was not included in the forms given to group 2. Thus, it was aimed to determine whether the minimum number of words instructions between the groups caused differences. Related to this field, data regarding the effect of word, sentence, link expressions, proverb, phrase, and the number of spelling and punctuation errors are located in Table 4.

Table 4. Minimum number of words instructions

\begin{tabular}{|c|c|c|c|c|c|c|}
\hline & $\begin{array}{l}\text { Groups of } \\
\text { Participating } \\
\text { Students }\end{array}$ & $\mathrm{N}$ & $\bar{X}$ & $\mathrm{Sd}$ & $\mathrm{T}$ & $\mathrm{P}$ \\
\hline \multirow{2}{*}{$\begin{array}{l}\text { Number } \\
\text { words }\end{array}$} & \multirow{2}{*}{$\begin{array}{l}\text { Group } 1 \\
\text { Group } 2\end{array}$} & 10 & 141,333 & 33,271 & 2,711 & \multirow[t]{2}{*}{, $016^{*}$} \\
\hline & & 10 & 94,6250 & 37,792 & 2,690 & \\
\hline \multirow{2}{*}{$\begin{array}{l}\text { Number } \\
\text { sentences }\end{array}$} & \multirow{2}{*}{$\begin{array}{l}\text { Group } 1 \\
\text { Group } 2\end{array}$} & 10 & 12,3333 & 4,6097 &, 502 & \multirow[t]{2}{*}{,623 } \\
\hline & & 10 & 11,2500 & 4,2342 & ,505 & \\
\hline \multirow{2}{*}{$\begin{array}{l}\text { Number of link } \\
\text { expressions }\end{array}$} & Group 1 & 10 & 10,8889 & 3,8550 & ,806 & \multirow[t]{2}{*}{,433 } \\
\hline & Group 2 & 10 & 9,0000 & 5,7321 &, 787 & \\
\hline \multirow{2}{*}{$\begin{array}{lr}\text { Number } & \text { of } \\
\text { proverb } & \text { and } \\
\text { idioms } & \\
\end{array}$} & \multirow{2}{*}{$\begin{array}{l}\text { Group } 1 \\
\text { Group } 2\end{array}$} & 10 & 2,7143 & 1,3801 & 1,584 & \multirow[t]{2}{*}{,139 } \\
\hline & & 10 & 1,8574 & ,37809 & 1,584 & \\
\hline \multirow{2}{*}{$\begin{array}{l}\text { Number of } \\
\text { spelling and } \\
\text { punctuation } \\
\text { errors }\end{array}$} & \multirow{2}{*}{$\begin{array}{l}\text { Group } 1 \\
\text { Group } 2\end{array}$} & 10 & 3,37 & 2,4458 & ,597 & \multirow[t]{2}{*}{,563 } \\
\hline & & 10 & 2,6 & 1,9493 & ,631 & \\
\hline
\end{tabular}

Note: Items marked (*) are items that are significant at $P<0,05$.

When the number of words in the texts written by the students participating in the study was examined in terms of the effect of minimum number of words instructions, the average number of words of group 1 was found to be 141,333 and the mean number of words of group 2 was 94,625. When this data were analyzed according to independent samples $t$ test, $\mathrm{p}<0,05$ results was obtained. This result shows that there is a significant difference between the groups in terms of the number of words. $(\mathrm{t}=$ $2,711,2,690, \mathrm{p}<0,05)$. According to these data, it can be said that the minimum number of words instructions affects the number of words in students' texts. As a matter of fact, it was found that the number of words of group 1 was higher than the other group.

When the number of sentences in the texts written by the students participating in the study was examined in terms of the effect of minimum number of words instructions, the average number of sentences of group 1 was found to be 12,33 and the mean number of sentences of group 2 was 11,25. When this data were analyzed according to independent samples $t$ test, $p>0,05$ results was obtained. This result shows that there is no significant difference between the groups in terms of number of sentences. ( $t=, 502,505 \mathrm{p}>0,05)$. According to these data, it can be said that the minimum number of words instructions does not affect the number of sentences in the students' texts. 
When the number of link expressions in the texts written by the students participating in the study was examined in terms of the effect of minimum number of words instructions, the average number of link expressions of group 1 was found to be 10,88 and the mean number of link expressions of group 2 was 9 . When this data were analyzed according to independent samples $t$ test, $p>0,05$ results was obtained. This result shows that there is no significant difference between the groups in terms of number of link expressions. ( $t=3,061,3,061, p>0,05)$. According to these data, it can be said that the minimum number of words instructions does not affect the number of link expressions in the students' texts.

When the number of proverb and idioms in the texts written by the students participating in the study was examined in terms of the effect of minimum number of words instructions, the average number proverb and idioms of group 1 was found to be 2,71 and the mean number of proverb and idioms of group 2 was 1,85 . When this data were analyzed according to independent samples $t$ test, $p>0,05$ results was obtained. This result shows that there is no significant difference between the groups in terms of number of proverb and idioms. $(t=1,5841,584, p>0,05)$. According to these data, it can be said that the minimum number of words instructions does not affect the number of proverbs and idioms in students' texts.

When the number of spelling and punctuation errors in the texts written by the students participating in the study was examined in terms of the effect of minimum number of words instructions, the average number of spelling and punctuation errors of group 1 was found to be 3,37 and the mean number of spelling and punctuation errors of group 2 was 2,6 . When this data were analyzed according to independent samples $t$ test, $p>0,05$ results was obtained. This result shows that there is no significant difference between the groups in terms of number of spelling and punctuation errors. ( $t=, 597,631, p>$ $0,05)$. According to these data, it can be said that the minimum number of words instructions does not affect the number of spelling and punctuation errors in students' texts.

\subsection{Findings of the compliance directive with spelling and punctuation rules}

In the research process, after the pre-test phase, the effect of the spelling and punctuation rules compliance on the texts written by the students was examined. At this stage, while the forms given to Group 1 contained the spelling and punctuation rules compliance instructions, the forms given to Group 2 did not include the spelling and punctuation rules compliance instructions. Thus, it is aimed to determine whether the compliance instructions with spelling and punctuation rules causes differences between the groups. Related to this field, data regarding the effect of word, sentence, link expressions, proverb, phrase, and the number of spelling and punctuation errors are located in Table 5.

Table 5. Spelling and punctuation rules

\begin{tabular}{|c|c|c|c|c|c|c|}
\hline & $\begin{array}{c}\text { Groups of } \\
\text { Participating } \\
\text { Students }\end{array}$ & $\mathrm{N}$ & $\bar{X}$ & $\mathrm{Sd}$ & $\mathrm{T}$ & $\mathrm{P}$ \\
\hline \multirow{2}{*}{$\begin{array}{l}\text { Number } \\
\text { words }\end{array}$} & \multirow{2}{*}{$\begin{array}{l}\text { Group } 1 \\
\text { Group } 2\end{array}$} & 10 & 86,600 & 40,321 &,- 749 & \multirow[t]{2}{*}{,465 } \\
\hline & & 10 & 103,00 & 52,714 &,- 726 & \\
\hline \multirow{2}{*}{$\begin{array}{l}\text { Number of } \\
\text { sentences }\end{array}$} & \multirow{2}{*}{$\begin{array}{l}\text { Group } 1 \\
\text { Group } 2\end{array}$} & 10 & 10,400 & 7,1833 &,- 308 & \multirow[t]{2}{*}{,762 } \\
\hline & & 10 & 11,375 & 5,9746 &,- 314 & \\
\hline \multirow{2}{*}{$\begin{array}{l}\text { Number of } \\
\text { link } \\
\text { expressions }\end{array}$} & \multirow{2}{*}{$\begin{array}{l}\text { Group } 1 \\
\text { Group } 2\end{array}$} & 10 & 7,1000 & 4,5326 &,- 990 & \multirow[t]{2}{*}{,337 } \\
\hline & & 10 & 9,1250 & 4,0155 & $-1,004$ & \\
\hline \multirow{2}{*}{$\begin{array}{l}\text { Number of } \\
\text { proverb and } \\
\text { idioms }\end{array}$} & \multirow{2}{*}{$\begin{array}{l}\text { Group } 1 \\
\text { Group } 2\end{array}$} & 10 & 1,7500 & ,95743 & ,000 & \multirow[t]{2}{*}{1,000} \\
\hline & & 10 & 1,7500 &, 50000 & ,000 & \\
\hline
\end{tabular}




\begin{tabular}{|c|c|c|c|c|c|c|}
\hline \multirow{2}{*}{$\begin{array}{l}\text { Number of } \\
\text { spelling and } \\
\text { punctuation } \\
\text { errors }\end{array}$} & \multirow{2}{*}{$\begin{array}{l}\text { Group } 1 \\
\text { Group } 2\end{array}$} & 10 & 2,2000 & 1,0954 &,- 420 & \multirow[t]{2}{*}{,683 } \\
\hline & & 10 & 2,6250 & 2,0658 &,- 483 & \\
\hline
\end{tabular}

When the number of words in the texts written by the students participating in the study was examined in terms of the effect of compliance with the spelling and punctuation rules instructions, the average number of words of group 1 was found to be 86,6 and the mean number of words of group 2 was 103. When this data were analyzed according to independent samples $t$ test, $p>0,05$ results was obtained. This result shows that there is a no significant difference between the groups in terms of the number of words. ( $t=-, 749-, 726, p>0,05)$. According to these data, it can be said that the compliance with the spelling and punctuation rules instructions does not affect the number of words in the students' texts.

When the number of sentences in the texts written by the students participating in the study was examined in terms of the effect of compliance with the spelling and punctuation rules instructions, the average number of sentences of group 1 was found to be 10,4 and the mean number of sentences of group 2 was 11,37. When this data were analyzed according to independent samples t test, $p>0,05$ results was obtained. This result shows that there is no significant difference between the groups in terms of number of sentences. $(\mathrm{t}=-, 308-, 314, \mathrm{p}>0,05)$. According to these data, it can be said that the compliance with the spelling and punctuation rules instructions does not affect the number of sentences in the students' texts.

When the number of link expressions in the texts written by the students participating in the study was examined in terms of the effect of compliance with the spelling and punctuation rules instructions, the average number of link expressions of group 1 was found to be 7,1 and the mean number of link expressions of group 2 was 9,12 . When this data were analyzed according to independent samples $t$ test, $\mathrm{p}>0,05$ results was obtained. This result shows that there is no significant difference between the groups in terms of number of link expressions. ( $t=-, 990-1,004, p>0,05)$. According to these data, it can be said that the compliance with the spelling and punctuation rules instructions does not affect the number of link expressions in the students' texts.

When the number of proverb and idioms in the texts written by the students participating in the study was examined in terms of the effect of compliance with the spelling and punctuation rules instructions, the average number proverb and idioms of group 1 was found to be 1,75 and the mean number of proverb and idioms of group 2 was 1,75 . When this data were analyzed according to independent samples $t$ test, $\mathrm{p}>0,05$ results was obtained. This result shows that there is no significant difference between the groups in terms of number of proverb and idioms. $t=, 000,000, p>0,05$ ). According to these data, it can be said that the compliance with the spelling and punctuation rules instructions does not affect the number of proverbs and idioms in students' texts.

When the number of spelling and punctuation errors in the texts written by the students participating in the study was examined in terms of the effect of compliance with the spelling and punctuation rules instructions, the average number of spelling and punctuation errors of group 1 was found to be 2,2 and the mean number of spelling and punctuation errors of group 2 was 2,62. When this data were analyzed according to independent samples t test, $p>0,05$ results was obtained. This result shows that there is no significant difference between the groups in terms of number of spelling and punctuation errors. $(\mathrm{t}=$ $, 420,483, \mathrm{p}>0,05)$. According to these data, it can be said that compliance with spelling and punctuation rules instructions does not affect the number of spelling and punctuation errors in students' texts. 


\section{Conclusion}

It is possible to list the results of this research in terms of the time used in writing activities, the effect of minimum number of words, spelling and punctuation rules on the texts of the students. The results of the research are as follows:

1. When the effect of the time instructions is examined, it is observed that group 1 has a higher average than group 2 in terms of the number of words and the number of connection expressions. In other variables, it was found that there was no difference between the groups in terms of the time instructions. According to these results, it can be said that the time instructions affects the written texts of the students in terms of the number of words and the number of connection statements.

2. When the effect of the minimum number of words instructions is examined, it is observed that group 1 has a higher average in terms of number of words than Group 2. In other variables, there was no significant difference between the groups. According to these results, it is possible to say that the minimum number of words instructions affects the written texts of the students in terms of the number of words.

3. It has been observed that the groups do not differ from each other when it comes to conforming to spelling and punctuation rules. This indicates that the compliance with spelling and punctuation rules does not affect the texts of the students in terms of the variables listed.

\section{Discussion}

According to the researchers, the texts written by the students are effective in determining their academic levels. Tiryaki (2013:43) states that texts written by individuals will contribute to the determination of their level of writing skills. As a matter of fact, assessment and evaluation activities are generally conducted in language lessons as in other branches were made with focus on written text. This is because written texts provide more concrete data to the teacher compared to speech. The frequent use of writing skills in educational processes requires special attention to its education. The level of the students to express themselves in writing and the qualitative and quantitative characteristics of the texts they write should be well determined. Because the findings in this direction will help to eliminate the missing learning and problems. The intensive use of writing skills by students in their educational processes has accelerated the efforts to improve this skill. There is research on the positive effects of various applications in the development of writing skills. Originality and creativity are important in writing process. In this subject, Aktaş (2009: 25) states that creative writing program is effective in holistic learning, development of cognitive skills and development of affective skills. Şengül (2011: 359) concluded that process-based writing has a positive effect on the development of students' written expression skills. Lea and Street (1998: 157) think that the "academic literacies" rather than traditional methods can be more effective in improving the writing skills of individuals. Writing skills are of course also influenced by personal characteristics. One of these features is the endearment of writing activities to the student. Göçer $(2010: 192)$ states that writing activities, must be for to make writing activities popular for students. Göçer (2010:192) states that in order to achieve this, these activities should be sufficient in terms of writing methods. According to the results of Fidan's (2018:36) research, type, size, subject and pictures are effective in making students interested in a text. It is thought that the texts that students enjoy reading can also affect cognitive and emotional writing process. In this respect, the development of writing methods has a holistic structure that includes the students' readiness, writing 
methods and techniques. One of these methods is the instructions used in writing forms. Therefore, the effectiveness of writing instructions in writing processes needs to be tested.

It is seen that the studies related to writing skills are mainly aimed at primary and secondary school students. However, Lillis and Turner (2001:57) stated that there are problems in students' writing skills in higher education. This situation requires that the trainings for improving writing skills should be applied not only in primary education, secondary education levels but also in upper (university) education levels. In this study, it is aimed to investigate the effect of some of the instructions used in the text writing process on students' writing skills. In fact, the conclusions reached may be important in revealing the impact and ineffectiveness of these instructions in several respects. When the results of the study are examined, it can be seen that some factors affect the writing process. The first of these factors is time. It is seen that students use more connection expressions in forms with time instructions. When we examine the forms where there are expressions for the minimum number of words, we see that there is a difference between the groups in terms of the number of words. This is important for the students to show that they are affected by the instruction in the form. When groups are examined in terms of spelling and punctuation rules, it is observed that there is no difference between groups. This indicates that the instructions on compliance with spelling and punctuation rules is not very effective on undergraduate students. In addition, there are some factors in this result. The students participating in the study are in the department of Turkish education. So they are knowledgeable in the field of mother tongue teaching. This is thought to be effective in complying with the spelling and punctuation rules.

In addition to individual competencies and abilities, the trainings received are effective in the development of individuals' written expression skills. This training process should be extended not only to the primary education, secondary education levels but also to the entire training processes. Because the development of written expression skills includes both traditionalism and innovation. Of course, these situations have an impact on the permanence of a written work. This situation requires the development of the written expression skills of the candidate teachers who will provide language education in schools and the ability to how they best gain to this skill to the students. It is considered that the application of similar studies to the students in primary education and secondary education levels will help to develop written activities for these students.

\section{References}

Aktaş, M. (2009). The effect of creative writing on achievement and on writing skill in foreign language teaching. Ankara Üniversitesi TÖMER Dil Dergisi, 145, 7-27.

Aktaş, Ş., Gündüz, O. (2017). Yazılı ve sözlü anlatım. Ankara: Akçağ Yayınları.

Ar1, G. (2011). The genre consistency between the reading and listening/viewing texts and writing tasks in Turkish (6th, 7th and 8th grades) course books. Turkish Studies, 6(3), 489-511.

Belet, D., Yaşar, Ş. (2007). Effectiveness of learning strategies over reading comprehension, writing skills and learners' attitudes towards Turkish course, Journal of Theory and Practice in Education, $3(1), 69-86$.

Breland, H. M., Jones, R. J. (1984). Perceptions of writing skills. Written Communication, 1, 101-119.

Demirbaş, A. (2005). Creative writing activities in biology teaching. Master's dissertation. Balıkesir University Institute of Science. Balıkesir.

Doğan, Y. (2003). Türkçe öğretmenliği birinci sınıf öğrencilerinin okuma ve yazma becerileri. TÜBAR, 13, 181-201. 
Englert, C.S., Raphael, T.E., Anderson, L.M., Anthony, H.M. \& Stevens, D.D. (1991). Making strategies and self-talk visible: writing instruction in regular and special education classrooms. American Educational Research Journal, 28(2), 337-372.

Erdoğan, Ö. (2017). Classroom teachers' opinions on the usage of writing strategies. Abant İzzet Baysal Üniversitesi Eğitim Fakültesi Dergisi, 17(1), 658-678.

Fidan, M. (2018). Evaluation of secondary school students' attitudes towards texts in Turkish textbooks. Erciyes Journal of Education, 2(1), 19-38.

Göçer, A. (2010). Writing education in Turkish teaching. The Journal of International Social Research, 3(12), 178-195.

Grossman, P. L., Valencia, S. W., Evans, K., Thompson, C., Martin, S., \& Place, N. (2000). Transitions into Teaching: Learning to Teach Writing in Teacher Education and Beyond. Journal of Literacy Research, 32(4), 631-662.

Günel, M., Kabataş Memiş, E., Büyükkasap, E. (2009). The effects of writing to learn activities and students' analogy construction on learning mechanic unit at the university level. Gazi Eğitim Fakültesi Dergisi, 29(2), 401-419.

Günel, M., Kabataş Memiş, E., Büyükkasap, E. (2010). Effects of the science writing heuristic approach on primary school students' science achievement and attitude toward science course. Education and Science, 35 (155), 49-62.

Güneş, F. (2013). Choosing the text in Turkish teaching. Journal of Mother Tongue Education, 1(1), $1-12$.

İnal, S. (2008). The perception system of brain, writing and clustering strategy. Doğuş Üniversitesi Dergisi, 9(1), 55-64.

Karakoç Öztürk, B. (2012). The study of writing anxiety of the elementary school students in terms of various variables. Ç.Ü. Sosyal Bilimler Enstitüsü Dergisi, 21(2), 59-72.

Karasar, N. (2009). Bilimsel araştırma yöntemleri (19. Bask1). Ankara: Nobel Yayın Dağıtım.

Kellogg, R.T. (2008). Training writing skills: A cognitive developmental perspective. Journal of

Writing Research, 1(1), 1-26.

Kepner, C. G. (1991). An experiment in the relationship of types of written feedback to the development of second-language writing skills. The Modern Language Journal. 75 (3), 305-313.

Lea, M. R., Street, B. V. (1998). Student writing in higher education: An academic literacies approach. Studies in Higher Education, 23(2), 157-172

Lillis, T., Turner, J. (2001). Student writing in higher education: Contemporary confusion, traditional concerns, Teaching in Higher Education, 6(1), 57-68.

Mak, B., Coniam, D. (2008). Using wikis to enhance and develop writing skills among secondary school students in Hong Kong. ScienceDirect, 36, 437-455.

MEB. (2018). Turkish course curriculum. Ankara: MEB.

Öztürk, E. (2007). The development of progress of creative writing and teaching of creative writing at primary school. Sakarya Üniversitesi Eğitim Fakültesi Dergisi, 14, 266-273.

Rao, Z. (2007). Training in brainstorming and developing writing skills. ELT Journal, 61(2), 100-106. 
Şengül, M. (2011). Evaluation of the effectiveness in practise of instruction and measurementassessment approaches in terms of writing skills in middle school Turkish. Doctoral dissertation, Firat University, Elazı $\breve{g}$.

Tiryaki, E.N. (2013). Writing education in teaching Turkish as a foreign language. Journal of Mother Tongue Education, 1(1), 38-44.

Ungan, S. (2007). Develepment of and importance of writing ski1ls. Erciyes Üniversitesi Sosyal Bilimler Enstitüsü Dergisi, 23, 461-472.

\section{Yazma yönergelerinin öğrencilerin yazma becerilerine etkisinin değerlendirilmesi}

\section{$\ddot{O} \mathbf{z}$}

Dil becerilerinin gelişmesi hem bireysel hem de toplumsal düzeyde önemli konumda bulunur. Bu becerilerden biri olan yazma, bireylerin kendilerini ifade etmelerinin hem estetik hem de kalıcı olmasını sağlamaktadır. Yazmanın bu önemi onun geliştirilmesine yönelik eğitimlere özel önem verilmesini gerektirmektedir. Bu araştırmada nicel araştırma yöntemlerinden tarama modeli kullanılmıştır. Üniversite öğrencilerinin yazdıkları metinlerin, yazılı formlarda kullanılan yönergelerden nasıl etkilendiği bu araştırmanın konusu olmuştur. Araştırmaya eğitim fakültesi öğrencileri katılmıştır. Bu öğrenciler deney ve kontrol grubu olarak ikiye ayrılmış̧ır. Araştırma sonucunda yönergelerin sözcük sayısı ve bağlantı ifadeleri açısından etkili olduğu görülmüştür. Yazı ve noktalama kurallarına uyum açısından ise yönergelerin bu gruplar düzeyinde etkisinin olmadığı tespit edilmiştir.

Anahtar Sözcükler: Yazma becerileri; yazma stratejileri;yazma yönergesi

\section{AUTHOR BIODATA}

He completed his undergraduate and graduate studies at Erciyes University, Department of Turkish Education. He received his $\mathrm{PhD}$ in Turkish Language Education from Atatürk University. He worked as a Turkish teacher for a while. He is currently working as a faculty member at Aksaray University, Faculty of Education, Department of Turkish Education. 